\title{
An Experimental Study on Concrete and Geomembrane Lining Effects on Canal Seepage in Arid Agricultural Areas
}

\author{
Xudong Han ${ }^{1}{ }^{1}$, Xiugui Wang ${ }^{1, *}$, Yan Zhu ${ }^{1}$, Jiesheng Huang ${ }^{1}$, Liqing Yang ${ }^{2}$, Zhifu Chang ${ }^{2}$ \\ and Feng $\mathrm{Fu}^{2}$ \\ 1 State Key Laboratory of Water Resources and Hydropower Engineering Science, Wuhan University, \\ Wuhan 430072, China; hanxudong@whu.edu.cn (X.H.); zyan0701@163.com (Y.Z.); \\ sdjshuang@whu.edu.cn (J.H.) \\ 2 Management Department of Yichang Irrigation Subdistrict, Hetao Irrigation District Management Bureau of \\ Inner Mongolia, Bayannur 015100, China; ylq13847801648@163.com (L.Y.); czf13294782585@163.com (Z.C.); \\ fufengwy@163.com (F.F.) \\ * Correspondence: wangxg@whu.edu.cn; Tel.: +86-153-3723-6043
}

Received: 11 July 2020; Accepted: 18 August 2020; Published: 20 August 2020

\begin{abstract}
Canal lining is commonly used to reduce seepage loss and increase water use efficiency. However, few studies have quantitatively estimated the seepage control effects of different lining materials under different service times. Ponding tests were conducted on the same canal section with four different lining statuses to investigate the canal lining effect on seepage control and its impact factors in arid areas. The cracks and holes in different lining materials were surveyed, and the canal seepage rates under the four test treatments were calculated by monitoring the water level change in the canal. The results show that the cracks in the joints of the two precast concrete slabs and holes in the geomembrane, which are located $0.25 \mathrm{~m}$ above the canal bottom on two sides of the canal, are responsible for the increased seepage loss. The new concrete and geomembrane lining combination reduces seepage by $86 \%$ compared with no lining, while seepage can be reduced by $68 \%$ using the concrete and geomembrane lining combination after three service years, and the amount decreases to $11 \%$ by using geomembrane lining with a three year service time. Based on the experiment and literature, a statistical relationship between the seepage reduction and lining service time was established, which provided a possible and easy way to estimate seepage losses from lined canals and improve the estimation accuracy using an empirical formula. Without considering the service time lining effect, the seepage loss is underestimated by $58 \%$, and the canal water use efficiency is overestimated.
\end{abstract}

Keywords: canal seepage; ponding test; canal lining; seepage losses; water conveyance efficiency

\section{Introduction}

In the past several decades, it has been a great challenge to maintain the sustainable use of water resources, especially in arid and semi-arid regions, due to increasing irrigation demands and climate change [1-3]. Since agricultural irrigation consumes the largest amount of water resources in some countries [4-8], decreasing agricultural water use becomes one of the most promising water-saving methods, in which the most important technology involves increasing water use efficiency [9]. A large amount of seepage loss is the main factor contributing to low water use efficiency when water is conveyed to fields by an irrigation system [10]. These seepage losses not only reduce the water efficiency of the canal system but also increase the groundwater table [11] and reduce water availability for domestic use downstream [12], leading to soil salinization and waterlogging [13]. 
There are many factors influencing canal seepage loss, including the canal cross-section profile, canal lining conditions, canal bed soil type, and groundwater table depth near the canal [6,14-16]. Canal lining is commonly used to reduce seepage loss, which has been proven to significantly increase the water conveyance efficiency [17]. However, canal linings are expensive and lose their efficacy gradually with service time. Significant seepage loss starts to occur from a lined canal after deterioration, especially with poor maintenance [18-20]. Thus, it is necessary to investigate the lining effect on controlling seepage loss to accurately estimate the agricultural water use efficiency and proper management of irrigation systems, effective irrigation plans, and irrigation project construction [21].

Many materials, such as geomembrane, bitumen, masonry, and concrete, have been reported in the literature to reduce seepage loss in canal lining [22-24]. Concrete and geomembrane are commonly used in most countries and are two kinds of main canal lining materials in China [25]. In Pakistan, test results have showed that the seepage losses through unlined canals were reduced $75 \%$ and $97 \%$ soon after construction by concrete and geomembrane, respectively [26]. In China, seepage loss can be reduced by $52-55 \%$, according to the ponding test results on two canals before and after being lined with concrete for one year [27]. Additionally, the canal seepage loss reduced by geomembrane lining was $96.33 \%$ in the main and branch canals and $76 \%$ in lateral canals [28]. According to the results of an inflow-outflow test conducted in Ethiopia, seepage losses from primary canals were reduced by $45.3 \%$ by the geomembrane lining [29]. In recent years, to further reduce canal seepage and prevent lining frost damage, two or more kinds of lining materials have been combined [30]. It was found that the canal seepage loss was decreased by $91 \%$ and $25 \%$ compared with using concrete or geomembrane alone [28]. Tiwari concluded that clay, concrete, and geomembrane reduced seepage losses by $60 \%$, $95 \%$, and $30 \%$, respectively [31]. The geomembrane combined with lime or clay could reduce seepage by $75 \%$. The abovementioned tests were carried out on lined canals with very short service times, e.g., one year after construction [27], soon after construction [26], and other studies did not point to the specific time after construction of the lining $[28,29,31]$. These studies indicated the seepage effect of the newly built lining but cannot represent the variation in the lining efficacy on controlling seepage loss during a long service time period. The effect of a single lining in concrete with a geomembrane lining is not explicit.

It is commonly found that the lining effect of seepage control varies with the maintenance condition and service time of the canal $[20,32,33]$. Many studies have reported that the permeability of lining material changes obviously with increasing service time due to aging of the lining materials [32], poor operation and maintenance [26,29], damage by plant roots or animals [34-36], and damage from frost heaving [37]. The lining performance of canals decreases with an increase in the rate of cracking in the concrete lining or holes in the geomembrane lining [38]. Holes in the geomembrane lining and concrete lining cracking are common phenomena after construction, especially in seasonally frozen ground regions [37,39]. In Kansas, US, a $60 \mathrm{~m}$ long canal lined with geomembrane was found to have approximately 200 holes after ten years following construction in May 1992. Moreover, at least 40 additional holes were observed in October 1995 [39]. Rowe et al. evaluated the performance of a high-density polyethylene (HDPE) geomembrane after 14 years as a leachate lagoon liner [40]. They observed that seven holes and 21 cracks were on the slopes and found that the permeability coefficients were between four and five times higher than the values obtained for unaged HDPE geomembranes. The geomembrane liner most likely stopped being effective as a contaminant barrier for ionic species sometime between $0-4$ years after installation, which was consistent with their discussion with the operators. Cracks are also commonly observed in concrete linings after construction [38,41]. The field investigation showed that the concrete lining in many canals was severely cracked after 8-9 years of construction, and minor cracking was observed in some other canals in the Khoozestan Province of Iran [42]. Swihart and Haynes reported that concrete lining started to develop cracks because of shrinkage during curing within the first couple of years and often continued to crack over time because of subgrade movement [41]. 
The abovementioned and other studies only mentioned the cracks and holes that occurred after the construction of the lining. However, only a few studies have focused on a quantitative description of the relationship between the quantity of cracks and holes and service time. Even fewer studies have investigated the change in the permeability of lining material with time and its relationship with the change in cracks or holes in the lining materials, which is important for quantitatively estimating the seepage control effect of lining canals under different service times. According to World Bank experts, canal lining with a $1 \%$ crack area has a seepage rate of $70 \%$ of that for unlined conditions [43]. Merkley also showed that if only $0.01 \%$ of the concrete canal lining is cracked, seepage in the lined and unlined canals is the same (i.e., no effect of the lining) [24]. Research has shown that there would be no difference in seepage losses between lined and unlined canals with the expansion of cracks on the canal surface [44].

The increase in the permeability of lining materials with time results in an increase in seepage loss, which obviously decreases the water efficiency of the canal [35,45]. Some researchers have concluded that the age or service time of the lining played an undeniable role in increasing the seepage losses [14,32]. The inflow-outflow method was used to measure the seepage loss under two canal sections with different service times in the Indus Basin of Pakistan, which showed that the lined canal under service times of $1-5$ years reduced seepage by $47 \%$, while it decreased to $30 \%$ under service times of 21-25 years compared with unlined canals [46]. The ponding tests were implemented in 103 canal sections to measure the seepage control effect under different service times of between 1-15 years [47]. However, few studies have estimated the explicit relationship between the seepage control effect of lining and service time. The studies were also carried out under different canal sections, in which the soil types of the canal bed and the nearby soil water characteristics were different. The difficulties in ensuring the same background condition in field experiments makes it difficult to find a benchmark for accurately estimating the relationship between the seepage control effect of the lining canal and the service time, which also makes it inaccurate to estimate seepage losses from lined canals using empirical equations [33].

The Hetao Irrigation District (HID) is in arid and semi-arid northern China with an irrigation area of 5.7 million ha. The irrigation water is mainly diverted from the Yellow River, which is approximately 4.7 billion $\mathrm{m}^{3}$ per year, accounting for $8 \%$ of the Yellow River runoff [48]. The irrigation water for HID from the Yellow River should be decreased to 4.0 billion $\mathrm{m}^{3}$ every year, as planned by the Chinese government [49]. The irrigation water use efficiency should be increased to 0.55 by 2030 to satisfy the requirement of agricultural development [50]. Canal lining is widely used in HID to increase the water efficiency of canal systems. From 1998 to the end of 2017, $1316 \mathrm{~km}$ of the main canals were lined, accounting for $20.8 \%$ of the total length. Single types of lining materials, including concrete with geomembrane, were frequently installed before the 2010s. A decrease in the seepage control of the lining canal has been found for long-term main, branch, lateral, and sub-lateral canals lined with concrete or concrete with geomembrane, which greatly decreases the water conveyance efficiency [51]. In recent years, a combination of different lining materials has been used to decrease seepage loss and prevent lining frost heave damage in HID [52]. Therefore, it is necessary to investigate whether the combination of different lining materials can guarantee the long-term durability of canal systems in this area.

This study investigated the seepage control effect change in the lining canal with service time and its relationship with the distribution of cracks and holes in lining materials. Four ponding tests were conducted on the same canal section with two kinds of different lining materials and a combination, and two service times, including no lining, a combination of new concrete and geomembrane lining, a combination of concrete and geomembrane lining with a service time of three years, and a geomembrane lining with a service time of three years. The cracks and holes in different lining materials were surveyed, and the canal seepage rates under the four test treatments were calculated. The attribution of cracks in the concrete and holes in the geomembrane to increase seepage loss were distinguished. Furthermore, the seepage control reduction factor with the service time was 
estimated by a simple linear formula, which can then be used to help calculate the water efficiency of the lined canal system after a specified service time.

\section{Materials and Methods}

\subsection{Study Area}

Field experiments were carried out at the Yonglian Experimental Station, which is located in the Renmin branch canal irrigation district $\left(41^{\circ} 0^{\prime} 52.17^{\prime \prime} \mathrm{N}-41^{\circ} 8^{\prime} 4.98^{\prime \prime} \mathrm{N}, 107^{\circ} 59^{\prime} 8.62^{\prime \prime} \mathrm{E}-108^{\circ} 1^{\prime} 48.79^{\prime \prime} \mathrm{E}\right.$ and altitude of $1028 \mathrm{~m}$ above sea level). The Renmin branch canal irrigation district is a part of the HID, as shown in Figure 1a. The climate in the area is arid continental, with average annual precipitation from $130 \mathrm{~mm}$ to $215 \mathrm{~mm}$ and average annual evaporation from water surface from $2100 \mathrm{~mm}$ to $2300 \mathrm{~mm}$ [53]. The freezing and thawing period lasts from late November to the middle of May, during which the maximum frozen depth is 1.0-1.2 m. The Renmin branch canal irrigation district is $12 \mathrm{~km}$ long from north to south and $3 \mathrm{~km}$ wide from east to west, with $29.75 \mathrm{~km}^{2}$ of farmland. The ground surface elevation decreases from $1028.9 \mathrm{~m}$ to $1025.4 \mathrm{~m}$ from southwest to northeast. The irrigation water is derived from the Yellow River by the Zaohuo trunk canal, delivered to the Renmin branch canal, and then distributed by its 25 lateral canals and 346 sub-lateral canals to fields. In April 2018, a field survey was conducted to determine the lining materials of each lateral and sub-lateral canal in the Renmin branch canal irrigation district. The locations and lining conditions of the lateral canals are shown in Figure 1a. The canal section of the Renmin canal, most of the lateral canals, and sub-lateral canals are trapezoidal. The main lining materials are concrete and geomembrane. The Renmin branch is approximately $12 \mathrm{~km}$, which was lined with concrete and geomembrane in 2014-2016. The laterals were lined with the concrete from 2000 to 2015. The total length of lateral canals with linings is approximately $21.11 \mathrm{~km}$, which accounts for $74 \%$ of the total length in the Renmin branch-controlled area. For sub-lateral canals, only the test canal was lined with concrete and geomembrane composite lining in 2015, and others are all unlined. The transformation of canals in the canal lining has been conducted in the study area to increase the water use efficiency.

The working regime of the canals in the area is as follows: the Renmin canal is continuously delivering water, and the lateral canals and sub-lateral canals are rotationally delivering water. The irrigation durations of canals in the same rotational group canal are equal. The gross discharge of the Renmin branch canal was approximately $1.0 \mathrm{~m}^{3} / \mathrm{s}$ according to the measurement. The field water efficiency is approximately 0.81 [54].

The ponding test was carried out on a sub-lateral canal of $30 \mathrm{~m}$ in length, the location of which is shown in Figure 1a. The average bottom width of the canal is $0.60 \mathrm{~m}$, the vertical depth is $0.55 \mathrm{~m}$ and the top width is $1.84 \mathrm{~m}$. The canal was lined by a combination of concrete and geomembrane in September 2015. The embankments on both sides of the canal were $1.5 \mathrm{~m}$ in width. The precast concrete panels were $0.6 \mathrm{~m}$ in length, $0.4 \mathrm{~m}$ in width, and $0.06 \mathrm{~m}$ in thickness, and the thickness of the polyethylene geomembrane was $0.3 \mathrm{~mm}$. There was an approximately $3 \mathrm{~cm}$ sand layer between the precast concrete slabs and the polyethylene geomembrane. The joint between the precast concrete slabs was filled with concrete mortar.

The hourly precipitation and evaporation data were obtained from the automatic weather station installed $200 \mathrm{~m}$ away from the canal. There was no precipitation during the four ponding tests. Evaporation rates during the tests of four treatments were $5.47,3.2,2.6$, and $2.0 \mathrm{~mm} / \mathrm{d}$, respectively. 
(a) Renmin canal irrigation district

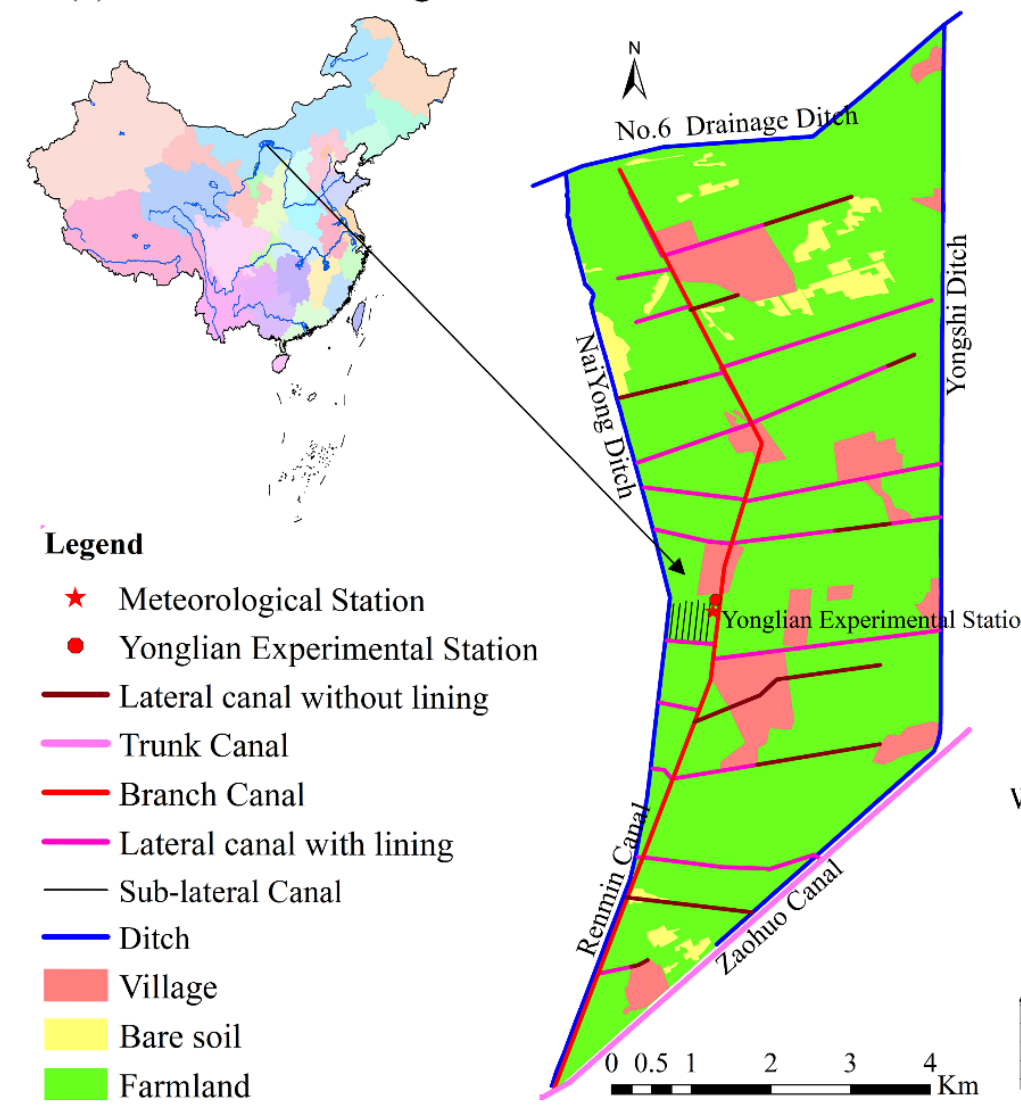

(b) Sketch of the experimental design

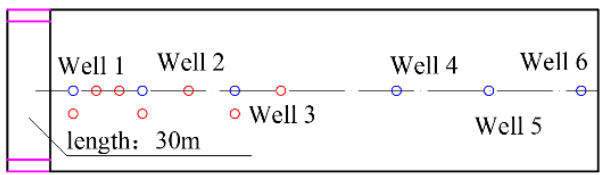

Well $\bigcirc$ TDR tube - Concrete barrier

(c) Sketch and section of the ponding test canal

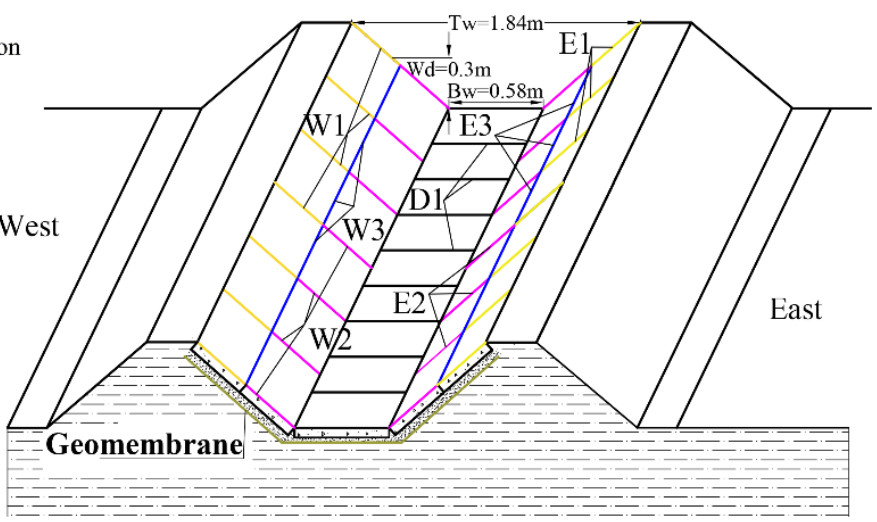

Figure 1. The study area location and detail information about ponding test. (a) The geographic location of the Renmin irrigation area. (b) Sketch of the experimental design. (c) Sketch and section of the ponding test canal. Note: D1 is the joints in the bottom of canal; "W1" and "W2" are the joints perpendicular to the direction of the canal in the upper and lower left side of the canal; "E1" and "E2" are the joints perpendicular to the direction of the canal in the upper and lower right side of the canal; "W3" and "E3" are the joints parallel to the direction of the canal in the left and right sides of the canal; "Tw" is the top width of canal; "Bw" is the bottom width of canal; "Wd" is the water depth in canal. 


\subsection{Ponding Test}

The ponding test was conducted according to the technical code for seepage control engineering on canals [55]. At each end of the $30 \mathrm{~m}$ experiment canal, two dikes were constructed with concrete and geomembrane, and the distance between the two dikes was approximately $1.5 \mathrm{~m}$ to form a water buffer to prevent water leakage from both ends. The ponding tests were carried out under four treatments according to the lining material of the canal, as listed in Table 1.

Table 1. Arrangement of four ponding treatments.

\begin{tabular}{cccccc}
\hline Treatment & Lining Material & $\begin{array}{c}\text { Canal Bottom } \\
\text { Width }(\mathbf{m})\end{array}$ & Slope & $\begin{array}{c}\text { Water Depth } \\
(\mathbf{m})\end{array}$ & Test Time \\
\hline $\mathrm{T} 1$ & $\begin{array}{c}\text { Old concrete and Old } \\
\text { geomembrane }\end{array}$ & 0.58 & $1: 1.13$ & 0.40 & $\begin{array}{c}\text { 22 September 2018 14:00- } \\
\text { 27 September 2018 14:00 }\end{array}$ \\
\hline $\mathrm{T} 2$ & Old geomembrane & 0.58 & $1: 1.60$ & 0.30 & $\begin{array}{c}\text { 29 September 2018 11:00- } \\
\text { 1 October 2018 23:00 }\end{array}$ \\
\hline $\mathrm{T} 3$ & No lining & 0.58 & $1: 1.60$ & 0.30 & $\begin{array}{c}\text { 3 October 2018 9:00- } \\
\text { 4 October 2018 23:00 }\end{array}$ \\
\hline $\mathrm{T} 4$ & $\begin{array}{c}\text { New concrete and } \\
\text { New geomembrane }\end{array}$ & 0.59 & $1: 1.19$ & 0.36 & $\begin{array}{c}\text { 12 October 2018 9:00- } \\
\text { 18 October 2018 9:00 }\end{array}$ \\
\hline
\end{tabular}

The first treatment was the combination of concrete and geomembrane lining with a service time of three years (marked as T1), which was based on the current lining condition of the canal. The second treatment was the geomembrane lining with a service time of three years (marked as T2), which was based on removing the precast concrete slabs when the ponding test of the T1 treatment was finished. The third treatment involved no lining (marked as T3) by removing the geomembrane when the ponding test of the T2 treatment was finished. After the ponding test of the T3 treatment, the canal was repaired and lined with a combination of new precast concrete slabs and new geomembrane, which was the fourth treatment, marked as T4. Before the experiment of each treatment, 10 sections of the canal were chosen to measure the canal section parameters, including the canal bottom width, slope, and water depth. The average section parameters of the four treatments are shown in Table 1.

Each ponding test was composed of a constant water level stage and a variable water level stage. During the constant water level stage, the water level variation was controlled within $5 \mathrm{~mm}$, which means that additional water should be replenished to the canal before the water depth dropped by $5 \mathrm{~mm}$. The change in water depth and duration time were recorded, which can be used to calculate the seepage rate. The constant water level stage was continued until the canal seepage rates of more than ten records remained stable, which means that the difference in the maximum and minimum seepage rates of the last records is smaller than $10 \%$ of the average seepage rate of the last ten records. Then, the variable water level stage started. The water depth dropped without replenishing the water. The water level was recorded automatically every $5 \mathrm{~min}$ by a water level gauge. The water depths in the four treatments were set as $0.4,0.3,0.3$, and $0.36 \mathrm{~m}$, as shown in Table 1 .

\subsection{Lining Damage Survey}

To determine the detailed reasons for the decrease in the seepage control effect of the lining material over time, the status of the joint mortar between the precast concrete slabs and the distribution of holes on the geomembrane were investigated and classified before the $\mathrm{T} 1$ treatment. When investigating the joint status, the location of joints was considered. As shown in Figure 1c, there are 7 kinds of joints distinguished by their locations, which are the joints in the bottom of the canal (marked as D1), joints perpendicular to the direction of the canal in the upper and lower left side of the canal (marked as W1 and W2), joints perpendicular to the direction of the canal in the upper and lower right side of the canal (marked as E1 and E2), and joints parallel to the direction of the canal in the left and right sides of the canal (marked as W3 and E3). The joint status was classified into three groups according to 
the type of filling material, marked as Groups A, B, and C, which are filled by mortar, earth, or no filling material, respectively. Group A can be further divided into three classes, marked as A1, A2, and A3; A1 indicates that the mortar was in good condition without any damage, A2 indicates that there were small holes or cracks in the mortar, and A3 indicates that the mortar was damaged by through cracks. Group B was also divided into two classes, marked as B1 and B2; the joint was fully filled by earth in B1, while the joint was partially filled with earth in B2. Furthermore, the position and diameter of holes, along with the location, length, and width of cracks on the geomembrane, were measured to evaluate the damage status of the geomembrane.

\subsection{Calculation of Ponding Test Results}

There are usually two indicators calculated by the ponding test to represent the seepage loss of the canal, e.g., seepage loss per unit length of the canal (named the seepage rate) and seepage loss per unit wet area (named the seepage intensity), which can be calculated as follows:

$$
\begin{gathered}
S=\Delta V / \Delta t-E+P, \\
Q_{s}=S / \chi,
\end{gathered}
$$

where $S$ is the canal seepage rate per unit length of the canal $\left(\mathrm{m}^{3} /(\mathrm{m} \cdot \mathrm{h}) ; \Delta V\right.$ is the change in stored water per unit length in the test section $\left(\mathrm{m}^{3} / \mathrm{m}\right) ; \Delta t$ is the length of observation duration (h); $E$ is the evaporation rate per unit length of the canal $\left(\mathrm{m}^{3} /(\mathrm{m} \cdot \mathrm{h}) ; P\right.$ is the precipitation per unit length of the canal $\left(\mathrm{m}^{3} /(\mathrm{m} \cdot \mathrm{h}) ; Q_{s}\right.$ is the infiltration intensity $\left(\mathrm{m}^{3} /\left(\mathrm{m}^{2} \cdot \mathrm{h}\right)\right)$; and $\chi$ is the wetted perimeter of the canal section $(\mathrm{m})$.

The reduction factor of the canal lining was used to describe the lining effect, which can be calculated as follows [56]:

$$
\beta=S_{l} / S_{s}
$$

where $\beta$ is the reduction factor of the lining; $S_{l}$ is the seepage rate per unit length of the canal after lining $\left(\mathrm{m}^{3} /(\mathrm{m} \cdot \mathrm{h})\right.$; and $S_{s}$ is the seepage rate per unit length of the canal before lining $\left(\mathrm{m}^{3} /(\mathrm{m} \cdot \mathrm{h})\right)$.

The contribution of the concrete or geomembrane in the composite lining was calculated as follows to indicate the effect of the single material in the composite lining.

$$
\begin{gathered}
C_{g}+C_{c}=100 \%, \\
C_{g} / C_{c}=\Delta S_{g} / \Delta S_{c},
\end{gathered}
$$

where $C_{g}$ is the contribution of geomembrane to the reduction in seepage; $C_{c}$ is the contribution of concrete to the reduction in seepage; $\Delta S_{g}$ is the seepage reduced by the geomembrane lining alone $\left(\mathrm{m}^{3} /(\mathrm{m} \cdot \mathrm{h})\right.$; and $\Delta S_{c}$ is the seepage reduced by the concrete lining alone $\left(\mathrm{m}^{3} /(\mathrm{m} \cdot \mathrm{h})\right)$.

The $\Delta S_{g}$ and $\Delta S_{c}$ are calculated by Equations (6) and (7) as follows:

$$
\begin{gathered}
\Delta S_{g}=S_{s}-S_{g}=S_{s}\left(1-\beta_{g}\right), \\
\Delta S_{c}=S_{s}-S_{c}=S_{s}\left(1-\beta_{c}\right),
\end{gathered}
$$

where $S_{S}$ is the seepage rate per unit length of canal before lining $\left(\mathrm{m}^{3} /(\mathrm{m} \cdot \mathrm{h})\right) ; S_{g}$ is the seepage rate per unit length of canal lined by geomembrane $\left(\mathrm{m}^{3} /(\mathrm{m} \cdot \mathrm{h})\right) ; \beta_{g}$ is the reduction factor of geomembrane lining alone time; $S_{c}$ is the seepage rate per unit length of canal lined by concrete $\left(\mathrm{m}^{3} /(\mathrm{m} \cdot \mathrm{h})\right) ; \beta_{c}$ is the reduction factor of concrete lining alone.

The $\beta_{c}$ is calculated by a multiplicative model according to literature [56] as Equation (8), and $\beta_{g}$ and $\beta_{c g}$ are calculated as Equations (9) and (10) as follows:

$$
\beta_{c}=\beta_{c g} / \beta_{g}
$$




$$
\begin{gathered}
\beta_{c g}=S_{o c g} / S_{s}, \\
\beta_{g}=S_{g} / S_{s},
\end{gathered}
$$

where $\beta_{c g}$ is the reduction factor of geomembrane and concrete combined lining; and $S_{o c g}$ is the seepage rate per unit length of canal lined by concrete and geomembrane $\left(\mathrm{m}^{3} /(\mathrm{m} \cdot \mathrm{h})\right) . S_{s}, S_{g}$ and $S_{o c g}$ are obtained from the ponding test results.

\subsection{Fitting of the Seepage Rate and Seepage Intensity}

To study the seepage rate variation with time during the stable water level stage of the four treatments, the modified Kostiakov model [57] was used to fit the relationship between the cumulative infiltration water and time during the four treatments. The modified Kostiakov model is outlined as follows:

$$
C I=k t^{A}+i_{c} t,
$$

where $C I$ is the cumulative infiltration at time $t\left(\mathrm{~m}^{3} / \mathrm{m}\right) ; t$ is the infiltration time $(\mathrm{h}) ; i_{c}$ is the infiltration rate at the steady state condition $\left(\mathrm{m}^{3} /(\mathrm{m} \cdot \mathrm{h})\right)$; and $k$ and $A$ are empirical constants, which can be obtained from curve fitting.

The relationship between seepage intensity and infiltration time was fitted by Equation (12). The fitted results $a$ and $b$ were used to calculate the seepage loss of other canals in the study area.

$$
Q_{s}=a h^{b},
$$

where $Q_{s}$ is the seepage rate at unit area $\left(\mathrm{m}^{3} /\left(\mathrm{m}^{2} \cdot \mathrm{h}\right)\right) ; h$ is the water depth in the canal $(\mathrm{m})$; and $a$ and $b$ are empirical constants obtained from the experimental results by curve fitting.

\subsection{Calculation of the Water Efficiency of the Canal System}

The water efficiency of the canal system can be calculated by the following formula:

$$
\begin{gathered}
\eta_{\text {s }}=I_{\text {out }} / I_{\text {in }}, \\
I_{\text {out }}=I_{\text {in }}-S_{\text {sum }}-E-W_{\text {other }}
\end{gathered}
$$

where $\eta_{\mathrm{s}}$ is the water conveyance efficiency of the canal system; $I_{\text {out }}$ is the water taken from the sub-lateral canals to the field $\left(\mathrm{m}^{3}\right) ; I_{\text {in }}$ is the total amount of water intake from the canal system $\left(\mathrm{m}^{3}\right)$; $S_{\text {sum }}$ is the total seepage water loss from the canal system $\left(\mathrm{m}^{3}\right) ; E$ is water loss due to evaporation from the canals in the study area $\left(\mathrm{m}^{3}\right)$; and $W_{\text {other }}$ is the water loss due to other reasons $\left(\mathrm{m}^{3}\right)$, such as overtopping the bunds, bund breakage and runoff in the drain.

Because canal seepage and evaporation loss are the main sources of water loss during water conveyance [19], and evaporation loss only accounts for a small amount of the total loss from the canal [58], $E$ and $W_{\text {other }}$ in Equation (14) are ignored, and Equations (13) and (14) is simplified as Equation (15)

$$
\eta_{s}=1-S_{\text {sum }} / I_{\text {in }}
$$

The total seepage water from the canal system can be calculated by summing the seepage water from a single canal as follows:

$$
S_{\text {sum }}=\sum_{i=1}^{n} \operatorname{Sep}_{i}
$$

where $\operatorname{Sep}_{i}$ is the total seepage water from canal $i\left(\mathrm{~m}^{3}\right)$, which is calculated by Equation (15):

$$
\operatorname{Sep}_{i}=\Delta t \sum_{j=1}^{n} \operatorname{Sep}_{i j},
$$


where $\operatorname{Sep}_{i}$ is the total seepage water from canal $i\left(\mathrm{~m}^{3}\right) ; \Delta t$ is the irrigation duration of the canal (h); and $S_{e p} p_{i j}$ is the seepage rate of segment $j$ in canal $i\left(\mathrm{~m}^{3} / \mathrm{h}\right)$.

$$
\operatorname{Sep}_{i j}=Q_{s j} \chi_{j} \beta_{j} \gamma_{j} \Delta L_{j}
$$

where $Q_{s j}$ is the seepage rate per unit wet area $\left(\mathrm{m}^{3} /\left(\mathrm{m}^{2} \cdot \mathrm{h}\right)\right)$ of segment $j$, which is calculated by Equation (10); $\chi_{j}$ is the wetted perimeter of the canal section in segment $j(\mathrm{~m}) ; \gamma_{j}$ is the reduction factor of the groundwater table depth in segment $j$, which is determined by the groundwater table depth and canal flow [56]; $\Delta L_{j}$ is the canal length of segment $j$; and $\beta_{j}$ is the reduction factor of the canal lining in segment $j$. It should be noted that the effect of the service time of the canal lining on $\beta$ was considered in this study.

\section{Results and Discussion}

\subsection{Damage Characteristics of Canal Lining}

The damage statuses of all joints among the precast concrete slabs in the $30 \mathrm{~m}$ experiment canal are listed in Table 2.

Table 2. The statistics of crack in concrete lining in different location.

\begin{tabular}{|c|c|c|c|c|c|c|c|c|c|}
\hline \multirow{2}{*}{ Joint Type } & \multicolumn{7}{|c|}{ Joint Location and Number of Cracks } & \multirow{2}{*}{ Sum } & \multirow{2}{*}{ Percentage $(\%)$} \\
\hline & D1 & W1 & W2 & W3 & E1 & E2 & E3 & & \\
\hline A1 & 60 & 27 & 32 & 2 & 19 & 31 & 14 & 125 & 44 \\
\hline $\mathrm{A} 2$ & 0 & 14 & 7 & 13 & 21 & 14 & 11 & 80 & 28 \\
\hline A3 & 0 & 3 & 4 & 8 & 2 & 1 & 5 & 23 & 8 \\
\hline B1 & 0 & 1 & 4 & 6 & 1 & 0 & 5 & 17 & 6 \\
\hline B2 & 0 & 0 & 1 & 11 & 2 & 0 & 7 & 21 & 8 \\
\hline $\mathrm{C}$ & 0 & 3 & 0 & 7 & 3 & 0 & 3 & 16 & 6 \\
\hline Sum & 60 & 48 & 48 & 47 & 48 & 46 & 45 & 282 & 100 \\
\hline
\end{tabular}

Note: D1 is the joints in the bottom of canal; "W1" and "W2" are the joints perpendicular to the direction of the canal in the upper and lower left side of the canal; "E1" and "E2" are the joints perpendicular to the direction of the canal in the upper and lower right side of the canal; "W3" and "E3" are the joints parallel to the direction of the canal in the left and right sides of the canal. D1, W1, W2, W3, E1, E2 and E3 are plotted in Figure 1c. A1 indicates that the mortar was in good condition without any damage. A2 indicates that there were small holes or cracks in the mortar, while A3 indicates that the mortar was damaged by perfoliate cracks. B1 indicates that the mortar was joint was fully filled by earth. B2 indicates that the mortar was joint was partly filled by earth. C indicates that joints do not have any filling material.

The total number of the joints in test canal was 282, which is equal to 940 per $100 \mathrm{~m}$ of canal. More than half of the joints on the two sides of the canal were damaged after three years. The damage statuses of A1 and A2 accounted for $44 \%$ and $28 \%$, respectively. The remaining damage statuses from $\mathrm{A} 3$ to $\mathrm{C}$ accounted for $28 \%$, which means that the damage of most joints was serious. More serious damage were found in the joints that were parallel to the canal direction (W3 and E3) compared with those perpendicular to the canal direction (W1, W2, E1 and E2), which may be caused by the frost heaving force since this area undergoes half of a year's seasonal freezing-thawing period [59]. The maximum frozen depth is deeper than $1.0 \mathrm{~m}$ in this area [60]. The tensile stress generated by frost heaving is smaller than the maximum allowable tensile stress of the concrete because of the small size of the slab, but the shear stress is equal to or larger than the allowable shear stress of the filling material [61]. Thus, the joints occurred prior to being damaged by the frost heaving force, which can release the tensile stress of the frost heaving and decrease the damage to the concrete slabs. This may result in major damage to mortar joints in this area. Figure 2 shows the sketch of mechanical failure of the concrete slab joints. The maximum bending moment caused by the frost heaving force occurred at a height of $1 / 3$ from the bottom to the top bank of the canal [52], which resulted in more serious 
damage to the W3 and E3 locations than the W1, W2, E1, and E2 locations. No damage was found on the joints between the precast concrete slabs at the bottom of the canal, as shown in Table 2. Although these joints encountered the frost heaving force, they were covered by silty soil, and there was a sand layer between the concrete slabs and geomembrane, which can relieve the damage of the frost heaving force. This finding is consistent with investigation results of other researchers [61].

(a) The sketch of initial concrete lining structure

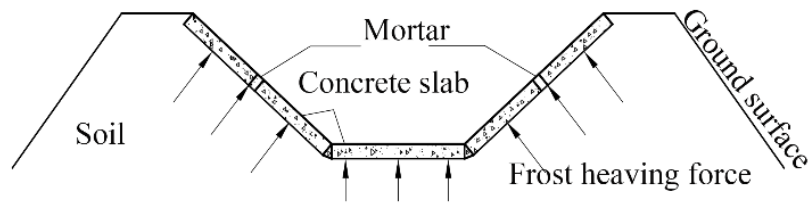

(b) The sketch of concrete lining damage

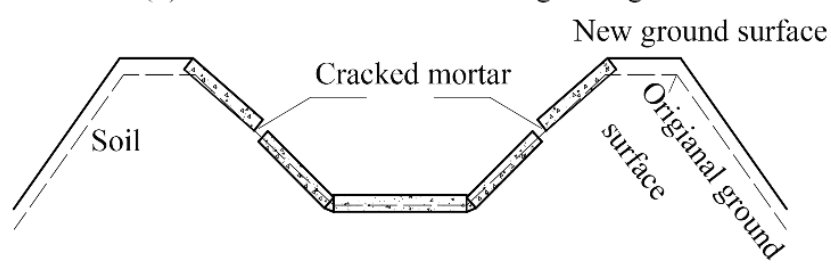

Figure 2. The sketch of mechanical failure of the concrete slabs joints. (a) The sketch of initial concrete lining structure. (b) The sketch of concrete lining damage.

There were 42 and 83 holes observed in the geomembranes of the west and east banks, respectively. The number and cumulative frequency of holes with different diameters on the geomembrane located on the west and east sides of the canal are shown in Figure 3.

- - Cumulative frequency in the west

--- Cumulative frequency in the east

- Cumulative frequency in the west and east

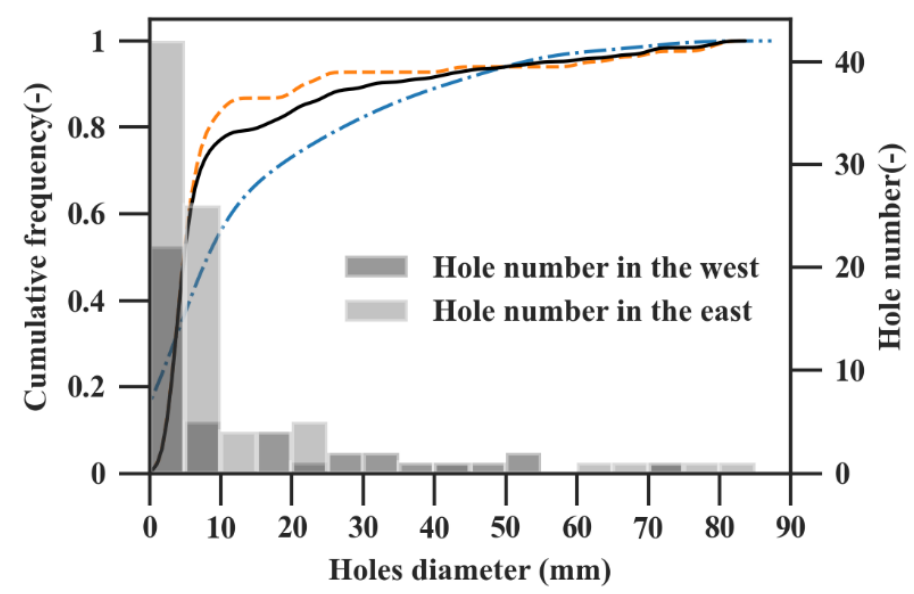

Figure 3. The number of holes with different diameters in the geomembrane and their cumulative frequency.

The holes with diameters smaller than or equal to $10 \mathrm{~mm}$ accounted for more than $78 \%$, the numbers of which on the left and right sides of the canal accounted for $86 \%$ and $64 \%$, respectively. These holes were mainly caused by weed roots. In addition, 15 holes with diameters larger than $25 \mathrm{~mm}$ accounted for $12 \%$, which was caused by the wooden wedge used to keep the geomembrane in place when it was installed. The distribution of hole numbers in the west and east banks at different heights is shown in Figure $4 a, b$. The distribution was fitted by the normal distribution, which is basically consistent 
with the statistical value distribution. The cumulative frequency of holes located at different vertical positions from the bottom of the canal on the geomembrane is shown in Figure 4c.

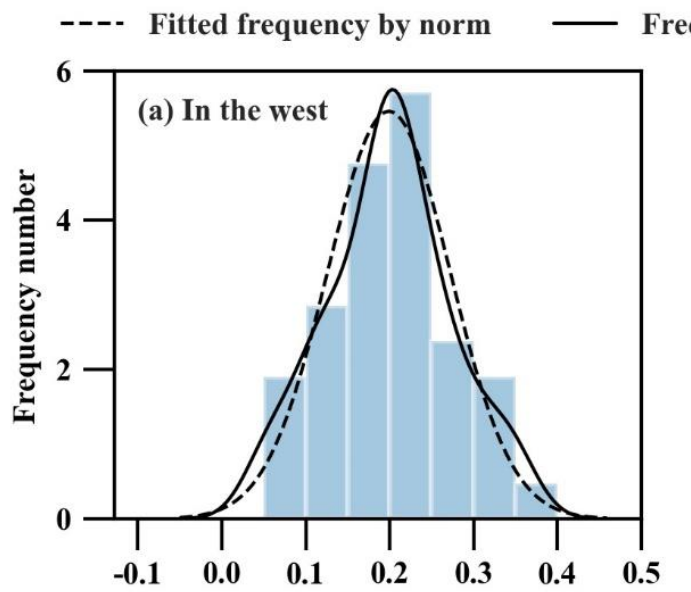

Height from bottom of canal (m)
Frequency of sample

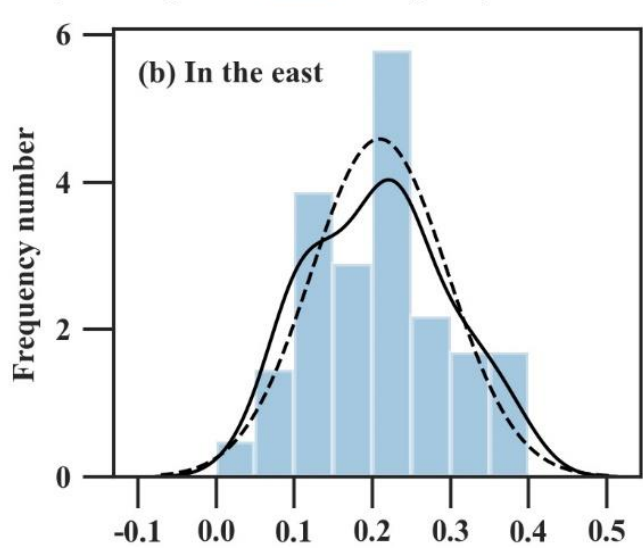

Height from bottom of canal (m)

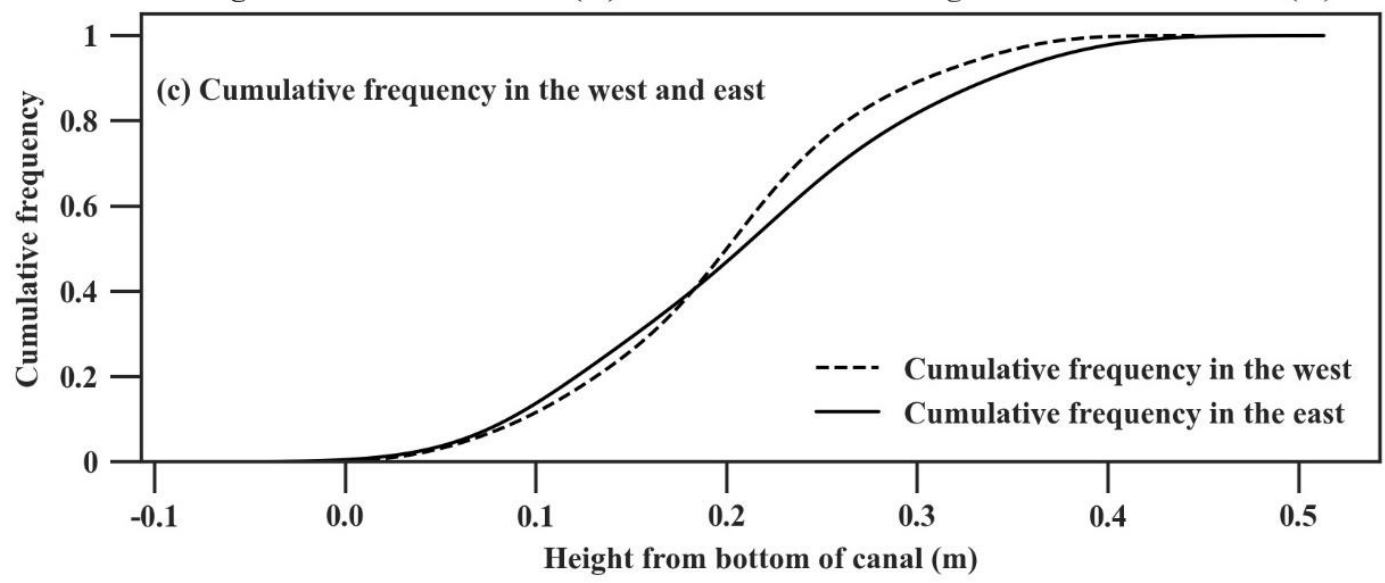

Figure 4. The number and cumulative frequency of holes in the geomembrane at different heights from the bottom of the canal. (a) The frequency number of holes in the geomembrane in west side of canal at different heights from the bottom of the canal. (b) The frequency number of holes in the geomembrane in east side of canal at different heights from the bottom of the canal. (c) Cumulative frequency of holes in the geomembrane at different heights from the bottom of the canal.

Since the hydrothermal conditions were almost the same for the two sides of the canal, the difference in the distribution of holes caused by weed root growth was very small. Therefore, the holes in the geomembrane of the canal sides were the same, and both obey a normal distribution. Most holes occurred within a height above the bottom of the canal of 14-34 cm, which was consistent with the distribution of weed roots on both sides of the canal. Weeds grew on those damaged joints on both sides of the canal and along the canal bank, which was the major cause of geomembrane damage. During the growing period, the weed roots grow through the lining and cause damage. Then, the damage left the holes, which made the water seep through the lining. This causes more serious damage the following year in terms of frost heaving. Similar results were found by Kraatz and Zhang Haiyan et al. [14,62]. This indicated that the weed grown at the bank and bottom of the canal should be removed in a timely manner to keep damage at bay.

\subsection{Infiltration during the Stable Water Level Stage}

The cumulative infiltration and its fitting equation by the modified Kostiakov model (see Equation (11)) during the stable water level stage during the four treatments are shown in Figure 5. 

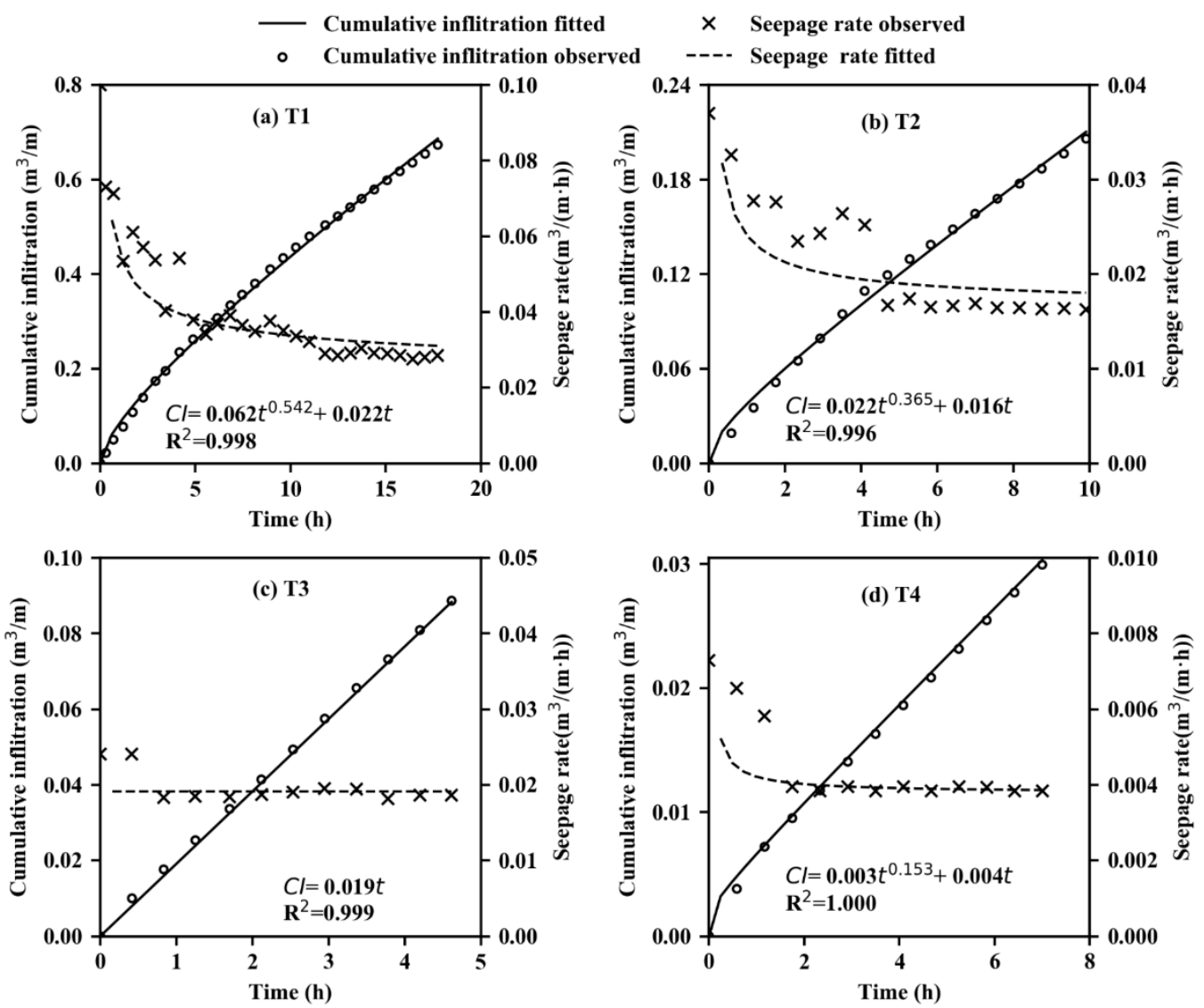

Figure 5. The cumulative infiltration and seepage rate per meter of canal for the four treatments: (a) T1; (b) T2; (c) T3; and (d) T4. Note: The canal lining of T1, T2, T3, and T4 treatment was geomembrane and concrete with a three year service time, geomembrane with a three year service time, no lining, and new precast concrete slabs and new geomembrane.

Obvious differences can be found in the infiltration time and cumulative infiltration at the end of the stable water level stage. It was approximately $17.74 \mathrm{~h}$ before the $\mathrm{T} 1 \mathrm{treatment}$ became stable, while it was $9.90,4.61$, and $7.00 \mathrm{~h}$ for the $\mathrm{T} 2, \mathrm{~T} 3$, and $\mathrm{T} 4$ treatments, respectively; the corresponding maximum cumulative infiltration water was $0.673,0.205,0.088$, and $0.300 \mathrm{~m}^{3} / \mathrm{m}$, respectively, which may be caused by the difference in the initial soil moisture. The drier soil has a larger infiltration capacity $[16,63]$. As a result, the T1 treatment had the largest maximum cumulative infiltration due to having the smallest soil moisture. The seepage rate was relatively large initially and gradually decreased to its stable seepage rate, as shown in Figure 5. This is a common infiltration process due to the increasing dominance of gravity-driven flow over capillarity-driven flow with increased penetration depth [16,64]. The steady seepage rates $\left(i_{c}\right)$ in the T1, T2, T3, and T4 treatments were $0.022,0.016,0.019$, and $0.004 \mathrm{~m}^{3} /(\mathrm{h} \cdot \mathrm{m})$, respectively. It can be found that $i_{c}$ in $\mathrm{T} 4$ was the minimum in terms of the best seepage control effect, which shows that canal seepage was obviously reduced by the newly installed composite lining. The canal water depths of the T2 treatment and T3 treatment were similar (see Table 1), but the $i_{\mathcal{c}}$ in the $\mathrm{T} 2$ treatment was $16 \%$ smaller than that in the T3 treatment, which suggested that the geomembrane with three years of service time had little seepage control effect. The $i_{c}$ of $\mathrm{T} 1$ is more than $\mathrm{T} 2$, which is due to the higher water depth $(0.4 \mathrm{~m})$ as shown in the Table 1 , and the incomplete geomembrane lining that the canal section above $0.25 \mathrm{~m}$ height from canal bottom were not totally covered by geomembrane lining for the reason of construction. 
3.3. The Seepage Rate under the Variable Water Depth Stage and the Seepage Control Effect under Different Canal Lining Treatments

The seepage rate under the variable water depth stage was calculated according to Equation (1), as shown in Figure 6.

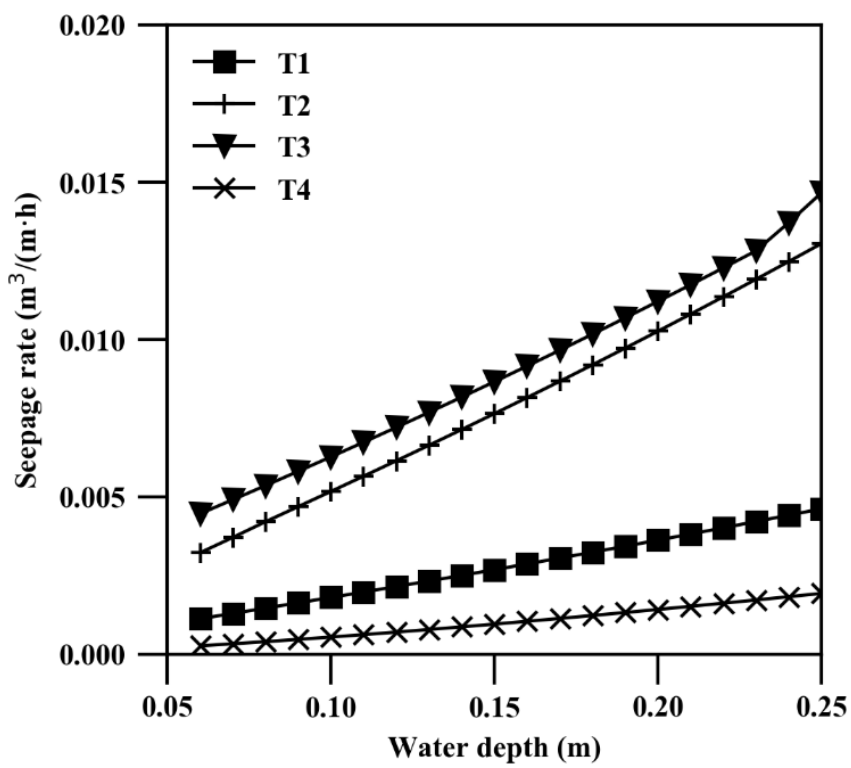

Figure 6. The canal seepage rate of four treatments. Note: The canal lining of T1, T2, T3, T4 treatment is geomembrane and concrete with a three year service time, geomembrane with a three year service time, no lining and new precast concrete slabs and new geomembrane.

The reduction factor $\beta$ under different canal lining treatments when the water depth was $25 \mathrm{~cm}$ was calculated by Equation (3), as listed in Table 3.

Table 3. The seepage rate reduced and reduction factor of each lining.

\begin{tabular}{cccccc}
\hline Lining Material & $\begin{array}{c}\text { New Concrete } \\
\text { and New } \\
\text { Geomembrane }\end{array}$ & $\begin{array}{c}\text { Concrete and } \\
\text { Geomembrane } \\
\text { (Both Three Years) }\end{array}$ & $\begin{array}{c}\text { Concrete } \\
\text { (Three Years) }\end{array}$ & $\begin{array}{c}\text { Geomembrane } \\
\text { (Three Years) }\end{array}$ & No Lining \\
\hline Seepage rate $(\mathrm{L} /(\mathrm{h} \cdot \mathrm{m}))$ & 1.94 & 4.63 & $6.24^{*}$ & 13.05 & 14.66 \\
\hline $\begin{array}{c}\text { Reduced seepage rate } \\
(\mathrm{L} / \mathrm{h} \cdot \mathrm{m}))\end{array}$ & 12.72 & 10.03 & $8.42^{*}$ & 1.61 & 0.00 \\
\hline Reduction factor & 0.14 & 0.32 & $0.35^{*}$ & 0.89 & 1.00 \\
\hline
\end{tabular}

* The result of concrete is estimated from seepage difference of T1 and T2 treatments.

It was found that there was little difference between the seepage rate in $\mathrm{T} 1$ treatment and $\mathrm{T} 2$ treatment at all canal water depths from Figure 6. Additionally the lining reduction factor of the T2 treatment when the water depth was $25 \mathrm{~cm}$ was 0.89 , which means that the geomembrane lining can reduce seepage loss by $11 \%$ after three years of service compared with the unlined canal. The result was similar to the research $[29,31]$, in which the seepage loss reduced by the geomembrane used was smaller than $30-35 \%$ and $45.3 \%$, respectively. However, this value was obviously smaller than those obtained by testing the new geomembrane lining [28,36,65], which is approximately $90 \%$, showing that the holes and cracks in the geomembrane can significantly decrease the seepage control effect, and their impacts should not be ignored.

As plotted in Figure 6, a larger seepage rate occurred in both of T2 treatment and T3 treatment than in the T1 treatments at different water depths. Table 3 also shows the seepage rate reduced and reduction factor of each lining condition when the water depth was $25 \mathrm{~cm}$. The reduction factor 
$\beta$ in the T1 treatment was 0.32 , which means that the combination of concrete and geomembrane lining with a service time of three years can still reduce seepage loss by $68 \%$ compared with the unlined T3 treatment. The seepage control effect was significantly improved when using geomembrane and concrete together, as the T2 treatment only reduced seepage loss by $11 \%$, which coincides with the conclusion by Akkuzu et al. [30] that the seepage control effect was obviously improved when geomembrane and concrete were used together. The possible reason is that the geomembrane was pressed by the concrete to be closely pressed to the soil, which increased the seepage path after the water passed through the holes or cracks along the contact surface of the geomembrane. The geomembrane also blocked cracks in some concrete slabs and lengthened the seepage path to decrease seepage losses.

From the comparison of the result of T1 treatment and T4 treatment in Figure 6 and Table 3, it can be seen that the absolute seepage loss from combined lining increased by $128 \%$ due to the lining damages (e.g., holes and cracks) after three years as discussed in Section 3.1, although 68\% seepage loss still can be reduced by the concrete and geomembrane lining after three years. However, the lining efficacy difference between $\mathrm{T} 1$ and $\mathrm{T} 4$ treatment is not very large, because most joints in concrete lining are not totally cracked (See Table 1), although the geomembrane with a three year service time has been close to non-functional.

Since the ponding test was not conducted on the canal lined only with precast concrete slabs with a service time of three years (marked as OC), the reduction factor $\beta$ of OC with a $25 \mathrm{~cm}$ water depth was obtained by comprehensively considering the seepage rate reduced by the T1 treatment and $\mathrm{T} 2$ treatment. The calculated reduction factor $\beta$ of OC was 0.35 , which showed that the precast concrete slab lining after three years of use can also reduce seepage loss by $65 \%$ compared with the unlined treatment. This value is close to $50-75 \%$ according to other researchers $[12,26,27]$. The experimental results of the present study show that the effect of the precast concrete slab lining was better than that of geomembrane lining under the same service time, although aged and cracked concrete lining are generally considered to decrease in terms of impermeability $[24,44,66]$.

To distinguish the contributions of geomembrane and precast concrete slab linings on the seepage control effect in the composite lining, the contribution of each was calculated according to Equations (4)-(10), as shown in Figure 7.

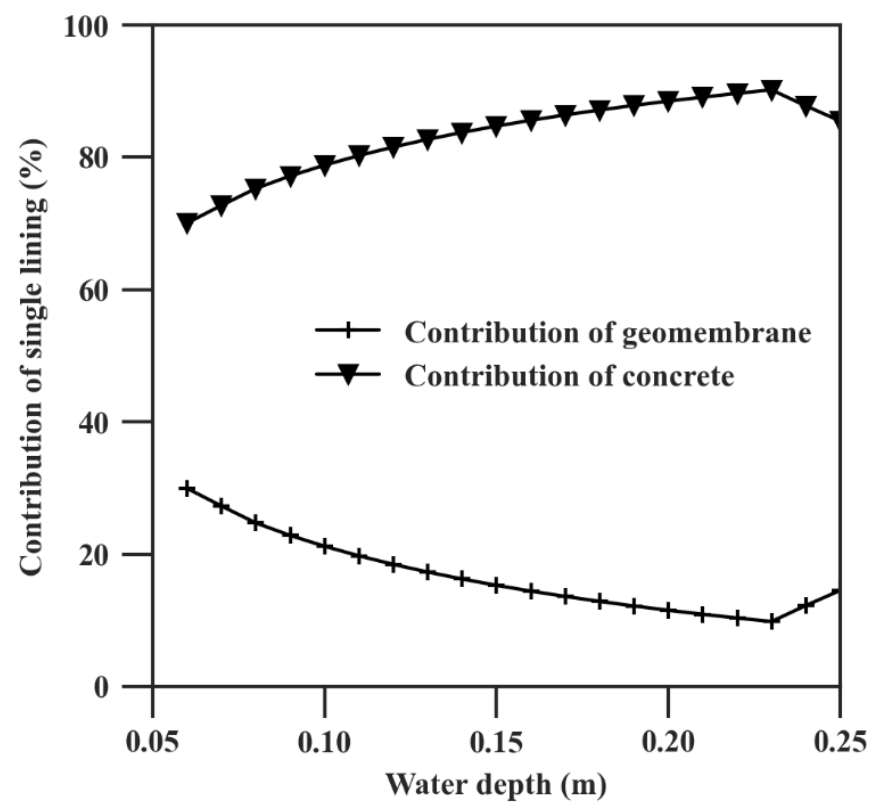

Figure 7. The contribution of concrete and geomembrane with a three year service time in the composite lining. 
Because the geomembrane damage was heavier than that of the concrete, the contribution of the concrete lining in combined lining was generally more than geomembrane lining. When the water depth in the canal increased from $5 \mathrm{~cm}$ to $25 \mathrm{~cm}$, the contribution of concrete increased from $70 \%$ to $90 \%$, but the contribution of geomembrane decreased from $30 \%$ to $10 \%$. The main seepage paths of the canal were cracks in the joints between precast concrete slabs and holes in the geomembrane. The crack size in the joint basically increased linearly with height away from the bottom of the canal, while the number of holes in the geomembrane increased with height from the bottom of the canal in a non-linear manner. The holes on the geomembrane below $24 \mathrm{~cm}$ from the bottom of the canal account for $71 \%$ of the total (Figure 4c). Therefore, the seepage control contribution of concrete in the composite lining increased with the water depth of the canal, while the geomembrane decreased.

\subsection{Relationship between the Seepage Control Effect of the Combination of Concrete and Geomembrane Lining} and the Service Time

The lining reduction factors of the combination of concrete and geomembrane lining under different service times collected from different studies are listed in Table 4. Two of them, representing service times of 0 years (T4 treatment) and three years (T1 treatment), were obtained by ponding tests in this study, and others were obtained from the literature. The reduction factor of the newly constructed lining with the concrete and geomembrane ranged from $0.03-0.15$, as listed in Table 4 . After two years, the reduction factor became 0.29 , and the values ranged from $0.32-0.34$ after three years. After 10 years, the reduction factor became 1.0, which shows that the canal lining lost its function [66]. The relationship between the seepage control effect of the combination of concrete and geomembrane lining and the service time is shown in Figure 8.

A linear fitting line was used to quantify the relationship between the reduction factor of the combination of concrete and geomembrane lining and its service time; see Equation (19):

$$
\beta=\min \left(1, \beta_{0}+\beta_{1} Y\right)
$$

where $\beta$ is the reduction factor; $Y$ is the service time (year); and $\beta_{0}$ and $\beta_{1}$ are the regression parameters, in which $\beta_{0}$ is the reduction factor of the lining at $Y=0$, and $\beta_{1}$ is the decrease rate in the reduction factor per year (1/year). According to the data in Table $4, \beta_{0}$ and $\beta_{1}$ were 0.08 and 0.09 , respectively. The fitting curve agreed well with the data, the $R^{2}$ of which was 0.99 , as shown in Figure 8. This equation provides a possible and easy way to estimate the seepage loss of lined canals for a given year.

Table 4. Statistical results of lining reduction factor in China from literatures.

\begin{tabular}{|c|c|c|c|c|}
\hline Service Time & Reduction Factor & Literature & Test Place & Remark \\
\hline 0 & 0.14 & \multirow{2}{*}{ This paper } & Inner Mongolia & Built in 2018, tested in 2018 \\
\hline 3 & 0.32 & & Inner Mongolia & Built in 2018, tested in 2018 \\
\hline 0 & $0.1-0.15$ & Literature [67] & Shaanxi & \\
\hline 0 & 0.05 & Literature [68] & Shaanxi & \\
\hline 10 & 1.0 & \multirow{2}{*}{ Literature [66] } & \multirow{2}{*}{ Inner Mongolia } & \multirow{2}{*}{ Lined after 2002, tested in 2012} \\
\hline 10 & 1.0 & & & \\
\hline 0 & 0.08 & Literature [69] & Shandong & Built in 2018, tested in 2018 \\
\hline 0 & 0.03 & Literature [28] & Ningxia & \\
\hline 4 & 0.46 & \multirow{3}{*}{ Literature [70] } & \multirow{3}{*}{ Inner Mongolia } & Built in 2014, tested in 2018 \\
\hline 2 & 0.29 & & & Built in 2016, tested in 2018 \\
\hline 3 & 0.34 & & & Built in 2015, tested in 2018 \\
\hline 5 & 0.5 & Literature [47] & Zhejiang & \\
\hline
\end{tabular}




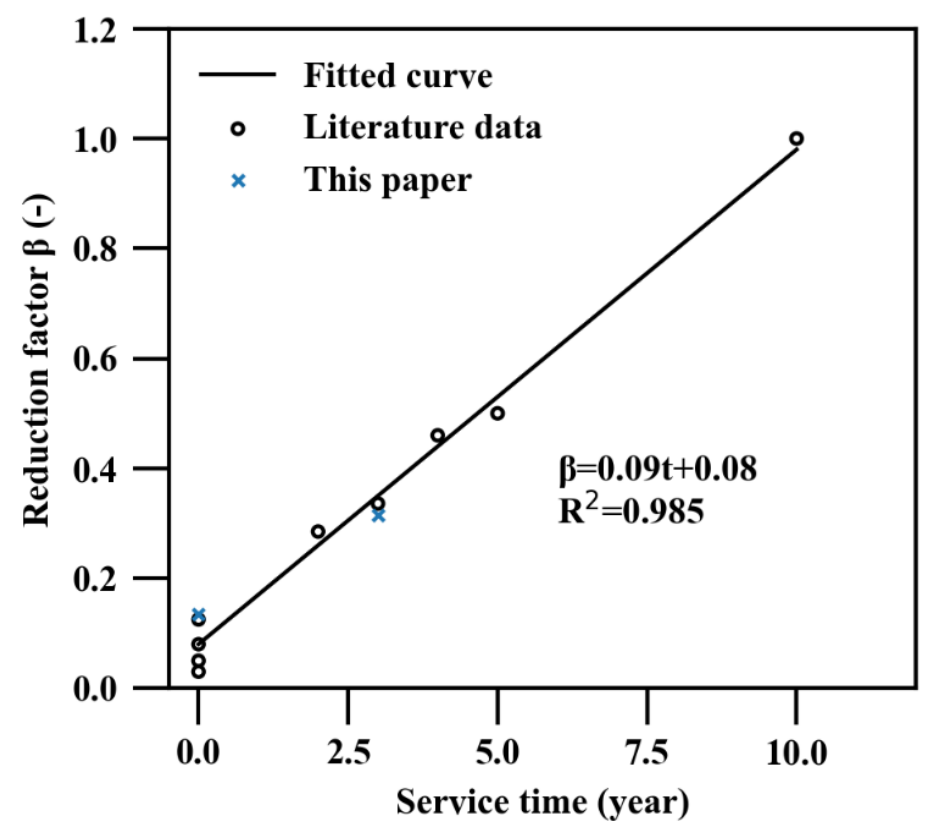

Figure 8. The relationship between the lining seepage reduction factor $(\beta)$ and service time $(t)$. Note: reduction factor $(\beta)$ is the proportion of seepage rate of a canal with lining to that without lining. A bigger reduction factor $(\beta)$ means more seepage rate from a lined canal.

\subsection{Estimation of the Water Efficiency of the Canal System in the Renmin Canal Irrigation Area under Different Scenarios}

To evaluate the water efficiency of the canal system in different transformation schemes, two scenarios were assumed as follows: (1) the lining status of all canals in the study area remained status quo (current status scenario); (2) all canals were relined by a new composite lining of concrete and geomembrane in 2018 (relined scenario). Assume that the initial year in the two scenarios was 2018. The water efficiency of the canal system, the seepage loss from the canal during autumn irrigation, and their variation trend between 2018 and 2030 were calculated.

\subsubsection{Comparison of both Methods to Calculate the Reduction Factor of the Canal Lining}

According to the method suggested by Ministry of Water Resources of China (MWRC) [65], the reduction factor of canal lining $\beta$ in Equation (18) is not changed with its service time. It is found that $\beta$ declines with service time, as shown in Equation (19). To compare the differences between the two methods, the seepage loss, water efficiencies of different levels of canals and water efficiency of the whole canal system in the Renmin canal irrigation area during autumn irrigation in the current scenario are listed in Table 5.

Table 5. Result of canal seepage loss and water efficiency of canal system.

\begin{tabular}{|c|c|c|c|c|c|c|c|c|}
\hline \multirow{2}{*}{$\begin{array}{c}\text { Methods } \\
\text { Canal }\end{array}$} & \multicolumn{3}{|c|}{$\begin{array}{c}\text { Reduction Factor Is Not Changed with } \\
\text { Service Time }\end{array}$} & \multicolumn{3}{|c|}{$\begin{array}{c}\text { Reduction Factor Declines with } \\
\text { Service Time }\end{array}$} & \multicolumn{2}{|c|}{ Seepage Loss Error } \\
\hline & $\begin{array}{l}\text { Gross Water } \\
\left(10^{3} \mathrm{~m}^{3}\right)\end{array}$ & $\begin{array}{l}\text { Seepage Loss } \\
\left(10^{3} \mathrm{~m}^{3}\right)\end{array}$ & $\eta_{s}$ or $\eta$ & $\begin{array}{l}\text { Gross Water } \\
\left(10^{3} \mathrm{~m}^{3}\right)\end{array}$ & $\begin{array}{l}\text { Seepage Loss } \\
\left(10^{3} \mathrm{~m}^{3}\right)\end{array}$ & $\eta_{s}$ or $\eta$ & $\begin{array}{c}\text { Absolute } \\
\text { Error }\left(10^{3} \mathrm{~m}^{3}\right)\end{array}$ & $\begin{array}{l}\text { Relative } \\
\text { Error }\end{array}$ \\
\hline Sub-lateral canals & 3874.99 & 105.11 & 0.973 & 3876.20 & 106.32 & 0.970 & -1.21 & $-1 \%$ \\
\hline Lateral canals & 3884.78 & 9.79 & 0.997 & 3937.35 & 61.15 & 0.984 & -51.36 & $-84 \%$ \\
\hline Branch canal & 3918.72 & 33.94 & 0.991 & 4088.71 & 151.36 & 0.963 & -117.42 & $-78 \%$ \\
\hline
\end{tabular}

Note: $\eta_{s}$ is water conveyance efficiency of canal system; $\eta$ is water conveyance efficiency of canal. 
The calculated water efficiency of the canal system when using Equation (19) to calculate the reduction factor was 0.922 with a gross irrigation water of the Renmin branch canal of 4.09 million $\mathrm{m}^{3}$, and the total seepage loss from the canals was 318.83 thousand $\mathrm{m}^{3}$. The seepage loss water from the sub-lateral canals, lateral canals, and branch canal was 106.32, 61.15, and 151.36 thousand $\mathrm{m}^{3}$, respectively. The water efficiency of the canal system when not considering the impact of service time on the reduction factor was 0.962 , with a total canal seepage loss of 148.84 thousand $\mathrm{m}^{3}$. The seepage loss water from the sub-lateral canals, lateral canals, and branch canal was 105.11, 9.79, and 33.93 thousand $\mathrm{m}^{3}$, respectively. According to the observation results of the Renmin canal flow, the total irrigation water from the Renmin canal was approximately $4,043,520 \mathrm{~m}^{3}$. Considering the error taken from ignoring evaporation and other losses, the estimated result 4.09 million $\mathrm{m}^{3}$ when considering the service time is closer to the observed value of $4,043,520 \mathrm{~m}^{3}$ during autumn irrigation. The seepage loss relative error of the canal system, branch canal, lateral canals, and sub-lateral estimation without considering the lining effect variation with time were $-53 \%,-78 \%,-84 \%$, and $-1 \%$, respectively, which shows that the temporal variation in the lining effect can not be ignored in the estimation of canal seepage loss. The results without consideration of the lining effect variation is similar to results of previous studies [33,35], in which there are big error in the seepage loss estimation result from lined canal by empirical equation (Moritz equation, Davis-Wilson equation) [14,30]. The proposed relationship between reduction factors is not only suitable in present study, but also can be adopted in existed empirical equations to improve the estimation accuracy.

\subsubsection{Estimation of the Water Efficiency of the Canal System in the Renmin Canal Irrigation Area}

The total seepage loss of the canal system and water conveyance efficiency results calculated under two scenarios by using Equation (19) to calculate the reduction factor is shown in Figure 9.

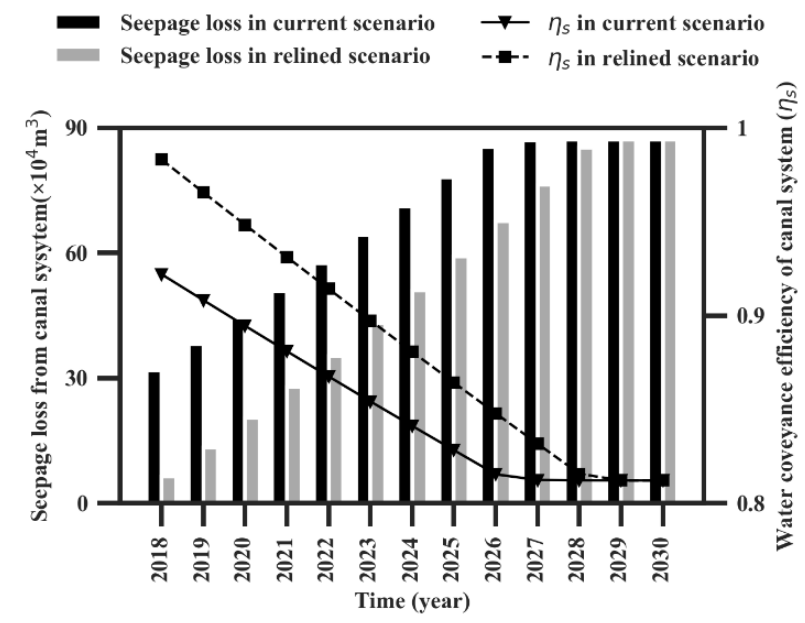

Figure 9. Estimation of seepage loss from canals and water conveyance efficiencies of the canal system $\left(\eta_{s}\right)$ in the reline scenario and current scenario in 2018-2030.

The seepage loss of the canal system in the relining scenario in the study area was $64,727 \mathrm{~m}^{3}$ smaller than $318,834 \mathrm{~m}^{3}$ in the current scenario in the first year. The water efficiency of the canal system increased from 0.922 in the current scenario to 0.983 in the relined scenario. This shows that the lining obviously reduces the seepage loss. However, as the newly built lining lacks sufficient maintenance and proper management with increasing service time, the seepage loss under the two scenarios increases, and the water efficiency of the canal system decreases until the lining loses its seepage control function. The average annual increase in seepage and the decrease in the water efficiency of the canal system in the two scenarios were $66,808 \mathrm{~m}^{3}$ and 0.013 and $76,446 \mathrm{~m}^{3}$ and 0.017 , respectively.

After 10.2 years, the lining lost all of its anti-seepage function, and the reduction factor became 1.0. The seepage loss from the canal system was $871,745 \mathrm{~m}^{3}$, and the water efficiency of the canal system 
was 0.81 , which is close to a similar irrigation system under high-level management in Portugal [71] and the $\eta_{s}$ of irrigation system without lining in Pakistan, which is $0.56-0.82$, when only the seepage losses is considered [14]. Due to the calculation, the other water loss and the variation of other canal condition (e.g., canal bed roughness etc.) except the seepage loss were ignored and the inflow was considered as a constant value, which means a high management level, the 0.81 is higher than the existing ordinary irrigation system. Compared to the current condition, if the canal lining is properly managed and repaired, the aging damage rate of the lining will be delayed, and the good seepage control function of the lining will be maintained. This means that parameter $\beta_{1}$ in formula (19) is lowered, and the service life of the canal is increased and more water can be saved in the whole service time of lining.

\section{Conclusions}

This study investigated the relationship between the seepage control effect change in the canal lining and service time by ponding tests. The cracks and holes in different lining materials were surveyed, and the attributions of the cracks in concrete and holes in the geomembrane to increase seepage loss were analyzed. A simple linear formula was established to represent the relationship between the seepage control reduction factor and the service time, which was used to estimate the water efficiency of the lined canal system after a certain service time. The main conclusions are as follows:

(1) The cracks in the mortar joints between the precast concrete slabs caused by frost heaving and holes on the geomembrane caused by grass roots contribute to an increase in the seepage loss of the lined canal.

(2) The seepage control effect of the composite lining is better than that of the separate lining because the concrete precast slabs and geomembrane were used together to compensate for each other's partial defects to enhance the function of the lining for each other.

(3) The lining effect decreases with service time, which is caused by the increase in cracks at the joint between the precast concretes and holes in the geomembrane. In the study area, the reduction factors of the composite lining in the current year and after three years were 0.14 and 0.32 , respectively.

(4) Based on the test results and existing literature, the relationship between the reduction factor $\beta$ and service time $Y$ of the composite lining can be expressed as $\beta=0.09 Y+0.08$. It was expected that the seepage control effect of the newly constructed lining would lose its function completely after 10.2 years. If the canal has proper management and maintenance, the service time of canal can be prolonged and more water can be saved by decreasing the canal seepage losses.

(5) The current method suggested by MWRC (2018) produces great error in the estimation of canal seepage because neglecting the lining function decreases with time. A case study showed that the relative error is approximately $53 \%$ and that the water conveyance efficiencies of the canal system in the current scenario and relined scenario were 0.922 and 0.983 , respectively.

(6) Limitation: More tests should be conducted for the perfection of parameter $\beta_{1}$ in different areas.

Author Contributions: Conceptualization, X.W. and J.H.; methodology, X.W. and J.H.; software, X.H.; validation, X.H., X.W., and Y.Z.; formal analysis, X.H.; investigation, X.W., L.Y., Z.C., and F.F.; resources, X.W.; data curation, X.H.; writing-original draft preparation, X.H.; writing—review and editing, Y.Z. and X.W.; visualization, X.H. and Y.Z.; supervision, X.W.; project administration, X.W.; funding acquisition, X.W. and Y.Z.; data collection L.Y., Z.C., and F.F. All authors have read and agreed to the published version of the manuscript.

Funding: This research was supported by the National Key Research and Development Program for the 13th Five-year Plan (grant number 2016YFC0400203) and Natural Science Foundation of China (grant numbers 51790533 and 51779178).

Acknowledgments: We thank Yiyi Deng and Liping Sun for their assistance in the experiment.

Conflicts of Interest: The authors declare no conflict of interest. 


\section{References}

1. Mariolakos, I. Water resources management in the framework of sustainable development. Desalination 2007, 213, 147-151. [CrossRef]

2. Fasakhodi, A.A.; Nouri, S.H.; Amini, M. Water Resources Sustainability and Optimal Cropping Pattern in Farming Systems; A Multi-Objective Fractional Goal Programming Approach. Water Resour. Manag. 2010, 24, 4639-4657. [CrossRef]

3. Cao, Y.; Zhang, W.; Ren, J. Efficiency Analysis of the Input for Water-Saving Agriculture in China. Water 2020, 12, 207. [CrossRef]

4. Hotchkiss, R.H.; Wingert, C.B.; Kelly, W.E. Determining irrigation canal seepage with electrical resistivity. J. Irrig. Drain. Eng. 2001, 127, 20-26. [CrossRef]

5. Alonso, A.; Feltz, N.; Gaspart, F.; Sbaa, M.; Vanclooster, M. Comparative assessment of irrigation systems' performance: Case study in the Triffa agricultural district, NE Morocco. Agric. Water Manag. 2019, 212, 338-348. [CrossRef]

6. Kinzli, K.D.; Martinez, M.; Oad, R.; Prior, A.; Gensler, D. Using an ADCP to determine canal seepage loss in an irrigation district. Agric. Water Manag. 2010, 97, 801-810. [CrossRef]

7. Yue, Q.; Zhang, F.; Guo, P. Optimization-Based Agricultural Water-Saving Potential Analysis in Minqin County, Gansu Province China. Water 2018, 10, 1125. [CrossRef]

8. Koech, R.; Langat, P. Improving Irrigation Water Use Efficiency: A Review of Advances, Challenges and Opportunities in the Australian Context. Water 2018, 10, 1771. [CrossRef]

9. Wallace, J.S. Increasing agricultural water use efficiency to meet future food production. Agric. Ecosyst. Environ. 2000, 82, 105-119. [CrossRef]

10. Wang, H.; Liu, C.; Zhang, L. Water-saving agriculture in China: An overview. In Advances in Agronomy; Academic Press: Cambridge, MA, USA, 2004; Volume 75, pp. 135-171, ISBN 9780120007936.

11. Upadhyaya, A.; Chauhan, H.S. Water table fluctuations due to canal seepage and time varying recharge. J. Hydrol. 2001, 244, 4-11. [CrossRef]

12. Meijer, K.; Boelee, E.; Augustijn, D.; van der Molen, I. Impacts of concrete lining of irrigation canals on availability of water for domestic use in southern Sri Lanka. Agric. Water Manag. 2006, 83, $243-251$. [CrossRef]

13. Singh, A. Waterlogging and Salinity Management for Sustainable Irrigated Agriculture. II: Engineering Measures and Biodrainage. J. Irrig. Drain. Eng. 2017, 143, 04017036. [CrossRef]

14. Kraatz, D.B. Irrigation Canal Lining; Food and Agriculture Organization of the United Nations: Rome, Italy, 1977.

15. Tabari, M.M.R.; Tavakoli, S.; Mari, M.M. Optimal Design of Concrete Canal Section for Minimizing Costs of Water Loss, Lining and Earthworks. Water Resour. Manag. 2014, 28, 3019-3034. [CrossRef]

16. Yao, L.; Feng, S.; Mao, X.; Huo, Z.; Kang, S.; Barry, D.A. Coupled effects of canal lining and multi-layered soil structure on canal seepage and soil water dynamics. J. Hydrol. 2012, 430-431, 91-102. [CrossRef]

17. Jadhav, P.B.; Thokal, R.T.; Mane, M.S.; Bhange, H.N.; Kale, S.R. Conveyance efficiency improvement through canal lining and yield increment by adopting drip irrigation in command area. Int. J. Innov. Res. Sci. Eng. Technol. 2014, 3, 120-129.

18. Barkhordari, S.; Hashemy Shahadany, S.M.; Taghvaeian, S.; Firoozfar, A.R.; Maestre, J.M. Reducing losses in earthen agricultural water conveyance and distribution systems by employing automatic control systems. Comput. Electron. Agric. 2020, 168, 105-122. [CrossRef]

19. Ghazaw, Y.M. Design and analysis of a canal section for minimum water loss. Alex. Eng. J. 2011, 50, 337-344. [CrossRef]

20. Kilic, M.; Tuylu, G.I. Determination of water conveyance loss in the ahmetli regulator irrigation system in the lower Gediz Basin Turkey. Irrig. Drain. 2011, 60, 579-589. [CrossRef]

21. Hameed, T.; Mariño, M.A.; Cheema, M.N. Time series modeling of channel transmission losses. Agric. Water Manag. 1996, 29, 283-298. [CrossRef]

22. Wilkinson, R.W.A. Plastic Lining on Riverton Unit, Wyoming. J. Irrig. Drain. Eng. 2008, 111, $287-298$. [CrossRef]

23. Moghazi, H.E.M.; Ismail, E.S. A study of losses from field channels under arid region conditions. Irrig. Sci. 1997, 17, 105-110. [CrossRef] 
24. Merkley, G.P. Irrigation Conveyance and Control: Flow Measurement and Structure Design, Lecture Notes for BIE 6300; Utah State University: Logan, UT, USA, 2007.

25. Soomro, A.; Qureshi, A.L.; Memon, N.A.; uddin Abro, Z. Efficacy of Watercourse Lining in Sindh-A Review Study in Relation with Kohistan Region. Agric. Sci. 2018, 9, 1215-1227. [CrossRef]

26. Snell, M. Lining old irrigation canals: Thoughts and trials. Irrig. Drain. 2001, 50, 139-157. [CrossRef]

27. Zhang, Q.; Chai, J.; Xu, Z.; Qin, Y. Investigation of Irrigation Canal Seepage Losses through Use of Four Different Methods in Hetao Irrigation District, China. J. Hydrol. Eng. 2017, 22, 1-11. [CrossRef]

28. Zhao, D. An analysis of ponding test results. Tech. Seepage Control 1997, 46, 21-24. (In Chinese)

29. Eshetu, B.; Alamirew, T. Estimation of Seepage Loss in Irrigation Canals of Tendaho Sugar Estate, Ethiopia. Irrig. Drain. Syst. Eng. 2018, 7, 3-7. [CrossRef]

30. Akkuzu, E.; Ünal, H.B.; Karataş, B.S. Determination of water conveyance loss in the Menemen open canal irrigation network. Turk. J. Agric. For. 2007, 31, 11-22. [CrossRef]

31. Akbar, S. Measurement of Losses from On-Farm Channels and Drains. Cooperative Research Centre for Sustainable Rice Production; Yanco Agricultural Institute: Yanco, Australia, 2005.

32. Moavenshahidi, A.; Smith, R.; Gillies, M. Seepage losses in the Coleambally Irrigation Area-loss estimates from channel automation data. Aust. J. Water Resour. 2016, 20, 78-88. [CrossRef]

33. Akkuzu, E. Usefulness of Empirical Equations in Assessing Canal Losses through Seepage in Concrete-Lined Canal. J. Irrig. Drain. Eng. 2012, 138, 455-460. [CrossRef]

34. Kahlown, M.A.; Kemper, W.D. Reducing water losses from channels using linings: Costs and benefits in Pakistan. Agric. Water Manag. 2005, 74, 57-76. [CrossRef]

35. Mohammadi, A.; Parvaresh Rizi, A.; Abbasi, N. Field measurement and analysis of water losses at the main and tertiary levels of irrigation canals: Varamin Irrigation Scheme, Iran. Glob. Ecol. Conserv. 2019, 18, e00646. [CrossRef]

36. Uchdadiya, K.D.; Patel, J.N. Seepage losses through unlined and lined canals. Int. J. Adv. Appl. Math. Mech. 2014, 2, 88-91.

37. Li, Z.; Liu, S.; Feng, Y.; Liu, K.; Zhang, C. Numerical study on the effect of frost heave prevention with different canal lining structures in seasonally frozen ground regions. Cold Reg. Sci. Technol. 2013, 85, 242-249. [CrossRef]

38. Zia, A.; Ali, M. Behavior of fiber reinforced concrete for controlling the rate of cracking in canal-lining. Constr. Build. Mater. 2017, 155, 726-739. [CrossRef]

39. Comer, A.; Kube, M.; Sayer, K. Remediation of existing canal linings. Geotext. Geomembr. 1996, 14, $313-325$. [CrossRef]

40. Rowe, R.K.; Sangam, H.P.; Lake, C.B. Evaluation of an HDPE geomembrane after 14 years as a leachate lagoon liner. Can. Geotech. J. 2003, 40, 536-550. [CrossRef]

41. Swihart, J.; Haynes, J. Canal-Lining Demonstration Project Year 10 Final Report; US Department of the Interior: Washington, DC, USA, 2002.

42. Rahimi, H.; Barootkoob, S. Concrete canal lining cracking in low to medium plastic soils. Irrig. Drain. 2002, 51, 141-153. [CrossRef]

43. Shivakumar, M.G. Performance Assessment of Irrigation Systems. Available online: https://www.icid.org/ china_ppts2018/training_ayp_china2018_5.pdf (accessed on 11 July 2020).

44. Swamee, P.K.; Chahar, B.R. Design of Canals; Springer: Berlin/Heidelberg, Germany, 2015.

45. Plusquellec, H. Modernization of government-managed irrigation systems in Syria and Middle East countries. In Proceedings of the Symposium on Irrigation Modernization, Damascus, Syria, 28-31 March 2006.

46. Raza, A.; Latif, M.; Shakir, A.S. Long-Term Effectiveness of Lining Tertiary Canals in the Indus Basin of Pakistan. Irrig. Drain. 2013, 62, 16-24. [CrossRef]

47. Jia, H.; Zheng, S. Theory, Method and Application of Irriagtion Water Use Efficiency; China Water Resources and Hydropower Press: Beijing, China, 2013. (In Chinese)

48. Feng, Z.Z.; Wang, X.K.; Feng, Z.W. Soil N and salinity leaching after the autumn irrigation and its impact on groundwater in Hetao Irrigation District, China. Agric. Water Manag. 2005, 71, 131-143. [CrossRef]

49. Sun, G.; Zhu, Y.; Ye, M.; Yang, J.; Qu, Z.; Mao, W.; Wu, J. Development and application of long-term root zone salt balance model for predicting soil salinity in arid shallow water table area. Agric. Water Manag. 2019, 213, 486-498. [CrossRef] 
50. Yang, J.; Li, F.; Shen, R. Warer Resources Planning Report of Bayan Nur, Inner Mongolia; Wuhan University and Water Administration of Bayan Nur: Wuhan, China, 2005. (In Chinese)

51. Zhou, L.; Zhao, H.; Liu, H. Analysis and prevention measures of frost heave damage of canal lining in Hetao Irrigation District. Inn. Mong. Water Resour. 2014, 1, 31-32. (In Chinese)

52. Mo, T.; Lou, Z. Numerical Simulation of Frost Heave of Concrete Lining Trapezoidal Channel under an Open System. Water 2020, 12, 335. [CrossRef]

53. Zhu, Y.; Shi, L.; Yang, J.; Wu, J.; Mao, D. Coupling methodology and application of a fully integrated model for contaminant transport in the subsurface system. J. Hydrol. 2013, 501, 56-72. [CrossRef]

54. Huang, Y.; Sun, W.; Qu, Z. Analysis of Field Water Utilization Efficiency and Regional Differentiation Rule in Hetao Irrigation. Water Sav. Irrig. 2015, 7, 99-102. (In Chinese)

55. Ministry of Water Resources of China (MWRC). Technical Code for Seepage Control Enginerring on Canal; China Planning Press: Beijing, China, 2010.

56. Guo, Y. Irrigation and Drainage Engineering, 3rd ed.; China Water Resources and Hydropower Press: Bejing, China, 1997. (In Chinese)

57. Stockinger, K.R. Movement of Water in Unsaturated Soils; Digital Repository@ Iowa State University: Ames, IA, USA, 1957; Volume 1. Available online: http://lib.dr.iastate.edu/ (accessed on 11 July 2020).

58. Xie, M.; Kuffner, U.; Le Moigne, G. Using Water Efficiently: Technological Options; The World Bank: Washington, DC, USA, 1993.

59. Yu, R.; Liu, T.; Xu, Y.; Zhu, C.; Zhang, Q.; Qu, Z.; Liu, X.; Li, C. Analysis of salinization dynamics by remote sensing in Hetao Irrigation District of North China. Agric. Water Manag. 2010, 97, 1952-1960. [CrossRef]

60. Xu, X.; Huang, G.; Qu, Z.; Pereira, L.S. Assessing the groundwater dynamics and impacts of water saving in the Hetao Irrigation District, Yellow River basin. Agric. Water Manag. 2010, 98, 301-313. [CrossRef]

61. Shen, X.; Zhang, Y.; Wang, L. Others Stress analysis of frost heave for precast concrete panel lining trapezoidal cross-section channel. Trans. Chin. Soc. Agric. Eng. 2012, 28, 80-85. (In Chinese)

62. Zhang, H.; Du, Y.; Zhang, J. Some Problems on seepage control of concrete channels. Adv. Sci. Technol. Water Resour. 2004, 73, 52-54. (In Chinese)

63. Parlange, J.Y.; Hogarth, W.L.; Barry, D.A.; Parlange, M.B.; Haverkamp, R.; Ross, P.J.; Steenhuis, T.S.; DiCarlo, D.A.; Katul, G. Analytical approximation to the solutions of Richards' equation with applications to infiltration, ponding, and time compression approximation. Adv. Water Resour. 1999, 23, 189-194. [CrossRef]

64. Barry, D.A.; Parlange, J.-Y.; Sander, G.C.; Sivaplan, M. A class of exact solutions for Richards' equation. J. Hydrol. 1993, 142, 29-46. [CrossRef]

65. Ministry of Water Resources of China (MWRC). Design Standard for Irrigation and Drainage Enginerring; China Planning Press: Beijing, China, 2018.

66. Yang, X. Evaluation of Canal-Systen Water Use Efficicency and Water Saving Potential in Hetao Irrigation District. Master's Thesis, Inner Mongolia Agrucultural University, Hohhot, China, 2015. (In Chinese).

67. Dong, Y. A disscussion on water-saving irrigation and application of cast-in-lplace lining and geomembrane lining in Baojixia Irrigation District. Sci. Technol. Inf. 2009, 17, 743. (In Chinese)

68. Xue, W. The Research on Effects of Water-Saving Irrigation on Soil Environment and Groundwater Level in Guanzhong Region. Master's Thesis, Xi'an University of Technology, Xi'an, China, 2017. (In Chinese).

69. Zhang, H.; Liu, H. The effect of canal lining in water saving on groundwater level. Tech. Superv. Water Resour. 2019, 2, 177-180. [CrossRef]

70. Water Diversion and Irrigation Engineering Technology Center Yellow River Institute of Hydraulic, Research; Mongolia, W.R.R.I. of I.; University, I.M.A. The Track Monitoring and Evaluation Report of Water Rights Transfer in Shenwu Irrigation Area of Hetao Irrigation District between the Citys of Inner Mongolia on the Main Yellow River. 2018; Unpublished Work.

71. Rijo, M.; Almeida, A.B. Performance of an automatic upstream controlled irrigation system: Conveyance efficiencies. Irrig. Drain. Syst. 1993, 7, 161-172. [CrossRef]

(C) 2020 by the authors. Licensee MDPI, Basel, Switzerland. This article is an open access article distributed under the terms and conditions of the Creative Commons Attribution (CC BY) license (http://creativecommons.org/licenses/by/4.0/). 